\title{
THE RELATIONSHIP BETWEEN DOSE OF PROGESTAGEN AND METHOD OF PREPARATION OF INTRAVAGINAL SPONGES ON THEIR EFFECTIVENESS FOR THE CONTROL OF OVULATION IN THE EWE
}

T. J. ROBINSON, T. D. QUINLIVAN* AND GHRISTINE BAXTER

Department of Animal Husbandry, University of Sydney, Sydney, N.S.W. 2006, Australia

(Received 2nd Fanuary 1968)

\begin{abstract}
Summary. The oestrous response and subsequent fertility to natural service of 360 cyclic Merino ewes were studied following treatment with intravaginal sponges impregnated with three dose levels of 'Cronolone' (9 $\alpha$-fluoro-11 $\beta$-hydroxy-17 $\alpha$-acetoxy-progesterone; Searle) and dried either in an oven or at ambient temperature. Sponges were inserted for 8 or 16 days and ninety were assayed for residual steroid after withdrawal.

The rate of absorption of Cronolone was a linear function of the amount present at any time, and was affected by the method of drying (oven $>$ air dried; $P<0.002)$ and initial dose $(10>20>30 \mathrm{mg} ; P<0.002)$.

The overall oestrous response with oven-dried sponges was higher than that with air-dried $(P<0.05)$ but the slight difference in fertility was not significant. There was an additive linear effect of dose of Cronolone $(10,20$ and $30 \mathrm{mg})$ on percentage of ewes in oestrus $(75 \cdot 8$, $81 \cdot 7,83.3$; N.S.), oestrous ewes which lambed $(61 \cdot 5,65 \cdot 3,74 \cdot 0$; N.S.), and total ewes which lambed of ewes treated $(46 \cdot 7,53 \cdot 3,61 \cdot 7 ; P<0 \cdot 05)$.

The significant interactions showed the $30-\mathrm{mg}$ oven-dried sponge, which released approximately $13.4 \mathrm{mg}$ Cronolone over a 16-day insertion period, to be highly effective. All of thirty ewes treated were in oestrus within 5 days of cessation, and $22(73.3 \%)$ lambed as a result of service at that oestrus.
\end{abstract}

\section{INTRODUCTION}

Despite the first reports of high fertility following the use of the intravaginal sponge technique for the synchronization of oestrus in cyclic ewes (Robinson, $1964,1965)$ subsequent work has shown conception rates often to be lower

* Present address: Box 231, P.O., Feilding, New Zealand. 
than normally expected (Robinson, Salamon, Moore \& Smith, 1967; Clarke, Roberts, Garter \& Kirton, 1966). Possible reasons for this have been discussed by the author (Robinson, 1967). A prime factor seems to be a failure of fertilization, due to an alteration in the pattern of sperm transport and survival (Quinlivan \& Robinson, 1967), associated with failure of the progestagen released by the impregnated sponge to maintain the endometrium in a normal state (Quinlivan, 1967).

The dose of progestagen incorporated into the sponge has been shown to have an effect on subsequent fertility (Robinson, Moore, Holst \& Smith, 1967; Robinson \& Smith, 1967; Robinson, Salamon, Moore \& Smith, 1967). Glearly, the amount of steroid actually released from the sponge, and the uniformity of this release over the 16-day period of intravaginal insertion, is more important than the dose impregnated. In the first report of rate of absorption, Morgan, Lack \& Robinson (1967) reported a relatively rapid (16\%/day of residual steroid) release of $9 \alpha$-fluoro-11 $\beta$-hydroxy-17 $\alpha$-acetoxy-progesterone (SC-9880'Cronolone'; Searle) from prototype commercial sponges. Subsequent assays on commercial sponges (Syncro-Mate; Searle) showed a much slower rate of release, despite an apparently similar method of preparation (unpublished results). One possible cause of this difference was the method of drying which could affect crystal size and consequent availability of the steroid.

This paper describes an experiment designed to compare the rate of absorption of Cronolone from intravaginal sponges impregnated with three dose levels and dried in two different ways. The relationship between the type of sponge and the oestrous response and subsequent fertility was also studied.

The field experiment was conducted at the McCaughey Memorial Institute, Jerilderie, N.S.W., between February and August 1967, and the assays of residual Gronolone in our laboratories at Camden, N.S.W.

\section{MATERIALS AND METHODS}

\section{Preparation of sponges}

The sponges were prepared and supplied by G. D. Searle and Co., High Wycombe, England. They were prepared by injecting the appropriate dose of Cronolone into the sponge in $1 \mathrm{ml}$ ethanol. One half were air-dried at ambient temperature (about $22^{\circ} \mathrm{C}$ ) and the other half oven-dried under infra-red heaters.

\section{Experimental animals}

Three hundred and sixty mature Merino ewes, each of which had previously borne a lamb, were used together with thirty-six Merino rams for natural mating.

\section{Design of the experiment}

A $2 \times 2 \times 3 \times 3$ factorial design $(n=10 ; \mathcal{N}=360)$ was used, incorporating the following factors.

Duration of insertion of sponges $\quad-\quad 8$ and 16 days

Method of preparation of sponges - Air-dried, oven-dried 
Dose of Cronolone

Date of withdrawal of sponges
- 10,20 and $30 \mathrm{mg}$

- 5th, 7th and 9th March.

Conduct of the experiment

Management. The 360 ewes were randomized into their twelve treatment groups and identified by numbered, coloured ear-tags. Insertion of sponges was staggered so that one-third of 8-day and of 16-day insertions would be removed on each of 3 alternate days, according to the following schedule:

$\begin{array}{cccc}\begin{array}{c}\text { Treatment } \\ \text { (duration of } \\ \text { insertion) }\end{array} & \begin{array}{c}\text { No. } \\ \text { of } \\ \text { ewes }\end{array} & \begin{array}{c}\text { Date of } \\ \text { insertion } \\ 1967\end{array} & \begin{array}{c}\text { Date of } \\ \text { withdrawal }\end{array} \\ \text { 16 days } & 60 & \text { 17th February } & \text { 5th March } \\ & 60 & \text { 19th February } & \text { 7th March } \\ & 60 & \text { 21st February } & \text { 9th March } \\ 8 \text { days } & 60 & \text { 25th February } & \text { 5th March } \\ & 60 & \text { 27th February } & \text { 7th March } \\ & 60 & \text { 1st March } & \text { 9th March }\end{array}$

Mating. Thirty-six rams fitted with 'Sire-sine' harnesses and crayons were joined with the ewes on removal of sponges and twice-daily inspections $(08.00$ and 17.30 hours) were made for services for the next 5 days. Ewes and rams were run in small mating paddocks. Returns to service one cycle later were also recorded.

Lambing. Ewes were lambed down in a small paddock adjacent to the sheep yards. Lambing was completed over a 10-day period at the end of which ewes were yarded and classed as 'wet' (lambed) or 'dry', and the number of lambs counted. The lambing data presented refer only to ewes which had lambed as a result of service at the oestrus immediately after sponge withdrawal.

Estimation of residual Cronolone in sponges. On removal, sponges were air-dried preparatory to extraction for residual steroid of samples from each method of drying, duration of insertion and dose combination. Ninety were extractedeighteen samples of five each from 10,20 and $30 \mathrm{mg}$ oven- or air-dried inserted for 0,8 or 16 days.

The method of estimation of Cronolone was by G.L.G. as described by Morgan et al. (1967) except that peak height rather than area was measured, and the method of extraction differed. Sponges were continuously extracted for $2 \mathrm{hr}$ with methylene chloride in a Soxhlet apparatus. Preliminary tests had shown this to be a more convenient method than extracting in a beaker with hot ethanol as previously described.

\section{Data recorded}

1. Ewes in oestrus within 5 days of removal of sponges.

2. Time of detection of oestrus.

3. Ewes which returned to service one cycle later.

4. Ewes which lambed.

5. Cronolone recovered from sponges after 0,8 or 16 days' insertion.

Analysis of data

All data were subjected to analysis of variance. Angular transformation was 
applied to those for oestrus and lambing, and log transformation to the chemical data. Regressions were calculated from the linear components of analyses of variance and lines of best fit determined by iterative procedures.

\section{RESULTS}

Table 1 presents the results of the main treatments on oestrus and lambing, with degrees of significance of main effects. Table 2 presents absorption, service and lambing data for all treatment combinations excepting date of withdrawal of sponges.

\section{TABLE 1}

THE NUMBERS AND PERGENTAGES OF EWES IN OESTRUS AND WHICH LAMBED FOLLOWING VARIOUS TREATMENTS WITH GRONOLONE-IMPREGNATED INTRAVAGINAL SPONGES

\begin{tabular}{|c|c|c|c|c|c|c|}
\hline \multirow{3}{*}{ Main effect } & \multirow{3}{*}{$\begin{array}{l}\text { Ewes } \\
\text { treated }\end{array}$} & \multicolumn{2}{|c|}{ Ewes in oestrus } & \multicolumn{3}{|c|}{ Ewes which lambed } \\
\hline & & \multirow{2}{*}{$\mathcal{N} o$. } & \multirow{2}{*}{$\%$} & \multirow{2}{*}{ No. } & \multicolumn{2}{|c|}{ Percentage } \\
\hline & & & & & $\begin{array}{l}\text { of ewes in } \\
\text { oestrus }\end{array}$ & $\begin{array}{l}\text { of total } \\
\text { treated }\end{array}$ \\
\hline \multicolumn{7}{|l|}{$\begin{array}{l}\text { Duration of insertion } \\
\text { (days) }\end{array}$} \\
\hline $\begin{array}{r}8 \\
16\end{array}$ & $\begin{array}{l}180 \\
180\end{array}$ & $\begin{array}{l}129 \\
160\end{array}$ & $\begin{array}{l}71 \cdot 7 \\
88 \cdot 9\end{array}$ & $\begin{array}{r}92 \\
102\end{array}$ & $\begin{array}{l}71 \cdot 3 \\
63 \cdot 8\end{array}$ & $\begin{array}{l}51 \cdot 1 \\
56 \cdot 7\end{array}$ \\
\hline$P$ & & \multicolumn{2}{|c|}{$<0.001$} & & N.S. & N.S. \\
\hline $\begin{array}{l}\text { Method of preparation } \\
\text { Air-dried } \\
\text { Oven-dried }\end{array}$ & $\begin{array}{l}180 \\
180\end{array}$ & $\begin{array}{l}138 \\
151\end{array}$ & $\begin{array}{l}76 \cdot 7 \\
83 \cdot 9\end{array}$ & $\begin{array}{r}91 \\
103\end{array}$ & $\begin{array}{l}65 \cdot 9 \\
68 \cdot 2\end{array}$ & $\begin{array}{l}50 \cdot 6 \\
57 \cdot 2\end{array}$ \\
\hline$P$ & & \multicolumn{2}{|c|}{$<0.05$} & & \multirow[t]{2}{*}{ N.S. } & \multirow[t]{2}{*}{ N.S. } \\
\hline Dose of Cronolone ( $\mathrm{mg}$ ) & & & & & & \\
\hline $\begin{array}{l}10 \\
20 \\
30\end{array}$ & $\begin{array}{l}120 \\
120 \\
120\end{array}$ & $\begin{array}{r}91 \\
98 \\
100\end{array}$ & $\begin{array}{l}75 \cdot 8 \\
81 \cdot 7 \\
83 \cdot 3\end{array}$ & $\begin{array}{l}56 \\
64 \\
74\end{array}$ & $\begin{array}{l}61 \cdot 5 \\
65 \cdot 3 \\
74 \cdot 0\end{array}$ & $\begin{array}{l}46 \cdot 7 \\
53 \cdot 3 \\
61 \cdot 7\end{array}$ \\
\hline $\begin{array}{l}P \text { linear } \\
\text { quadratic }\end{array}$ & & \multicolumn{2}{|c|}{$\begin{array}{l}\text { N.S. } \\
\text { N.S. }\end{array}$} & \multirow{3}{*}{$\begin{array}{l}78 \\
64 \\
52\end{array}$} & $\begin{array}{l}\text { N.S. } \\
\text { N.S. }\end{array}$ & $\begin{array}{l}<0 \cdot 05 \\
\text { N.S. }\end{array}$ \\
\hline $\begin{array}{r}\text { Date of withdrawal } \\
\text { 5th March } \\
\text { 7th March } \\
\text { 9th March }\end{array}$ & $\begin{array}{l}120 \\
120 \\
120\end{array}$ & $\begin{array}{r}104 \\
94 \\
91\end{array}$ & $\begin{array}{l}86 \cdot 7 \\
78 \cdot 3 \\
75 \cdot 8\end{array}$ & & $\begin{array}{l}75 \cdot 0 \\
68 \cdot 1 \\
57 \cdot 1\end{array}$ & $\begin{array}{l}65 \cdot 0 \\
53 \cdot 3 \\
43 \cdot 3\end{array}$ \\
\hline $\begin{array}{l}P \text { linear } \\
\text { quadratic }\end{array}$ & & \multicolumn{2}{|c|}{$\begin{array}{l}<0.05 \\
\text { N.S. }\end{array}$} & & $\begin{array}{l}<0.01 \\
\text { N.S. }\end{array}$ & $\begin{array}{l}0.01 \\
\text { N.S. }\end{array}$ \\
\hline Total & 360 & 289 & $80 \cdot 3$ & 194 & $67 \cdot 1$ & $53 \cdot 9$ \\
\hline
\end{tabular}

Experimental design $=$ Factorial $2 \times 2 \times 3 \times 3 ; n=10 ; \mathcal{N}=360$.

Loss of sponges and of ewes

Only one ewe lost her sponge and no ewes were lost in the course of the experiment.

Ewes in oestrus after sponge withdrawal

Ewes served. Of the 360 ewes treated, 289 were served 1 to 5 days after withdrawal of the sponges (Table 1). There were significant effects of duration of 


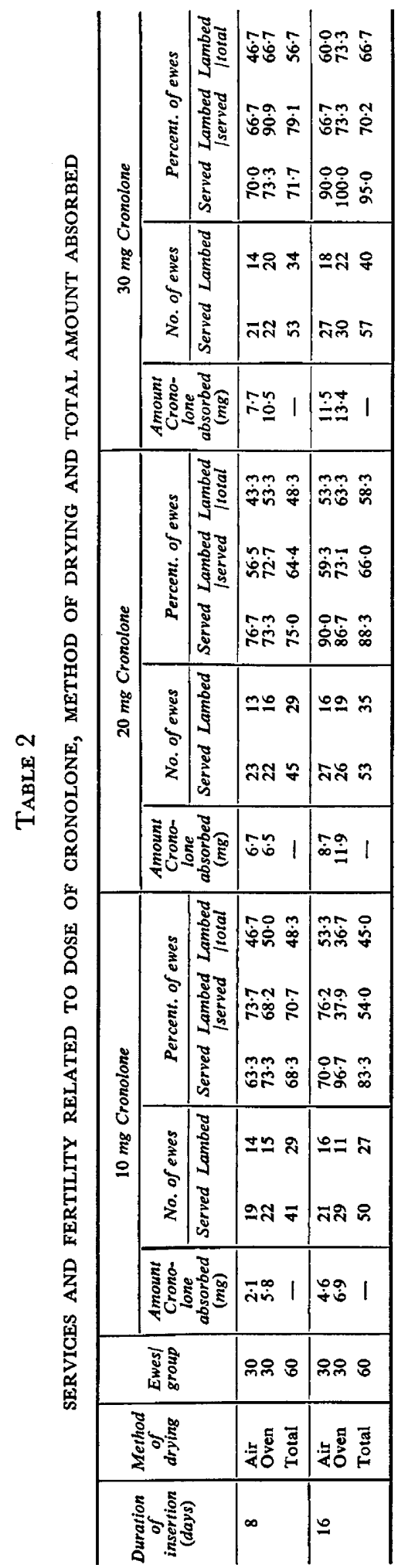


insertion ( 8 days, $129 ; 16$ days, $160 ; P<0.001$ ) and method of drying (air-dried, 138; oven-dried, $151 ; P<0.05)$ and date of withdrawal (5th March, 104; 7th March, 94; 9th March, 91; $P<0.05)$. The slight linear increase with dose $(10 \mathrm{mg}, 91 ; 20 \mathrm{mg}, 98 ; 30 \mathrm{mg}, 100)$ failed to attain significance $(P \fallingdotseq 0 \cdot 10)$.

There was a significant interaction between method of drying and dose $(P<0.05$, Text-fig. 1a). The oestrous response following the use of air-dried, 10-mg sponges was inferior to that following all others.

TABLE 3

DISTRIBUTION BY DAYS OF TIME OF DETECTION OF OESTRUS AFTER WITHDRAWAL OF CRONOLONE-IMPREGNATED INTRAVAGINAL SPONGES WITH ASSOCIATED LAMBING DATA

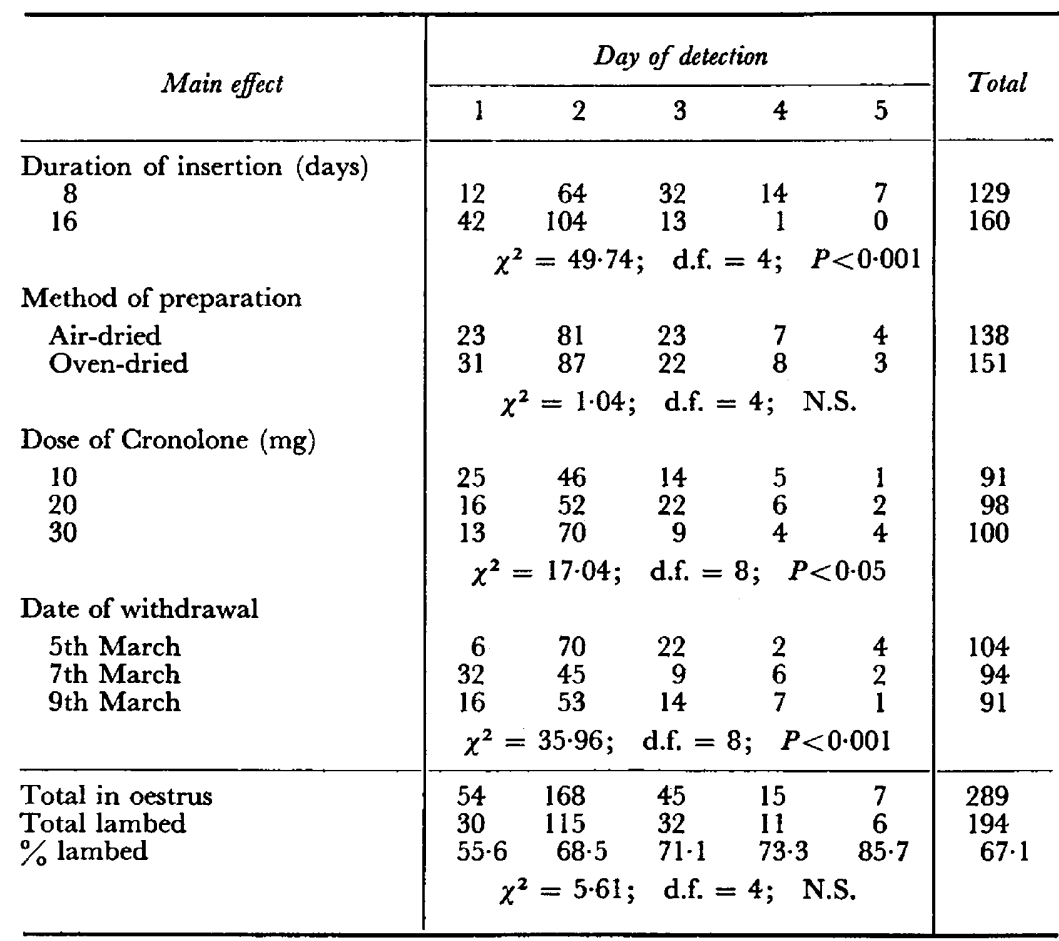

Sponges withdrawn a.m. on Day 0 .

Time of detection of oestrus

Table 3 presents the distribution of times of onset of oestrus, by daily intervals. Ewes treated for 16 days came into oestrus earlier than those treated for 8 days $(P<0.001)$. There were significant effects also of dose of Cronolone $(P<0.05)$ and of date of withdrawal $(P<0.001)$. Ewes which received the lowest dose came in earliest and those in which sponges were withdrawn later came into oestrus earlier. There was no significant effect of method of drying and no interactions. 
Returns to service

Of the 289 ewes served, seventy-nine $(27.3 \%)$ returned to service. Of the 210 non-returns $(72.7 \%), 194(67.1 \%)$ lambed, a discrepancy of sixteen or $5.5 \%$ of ewes served.

Of the seventy-one ewes not served, fifty-four were recorded in oestrus one cycle later, sixteen from the 16th day and thirty-eight from the 8th day of treatment. Hence, totals of 176 and 167 ewes were recorded in oestrus of the 180 in each time treatment.
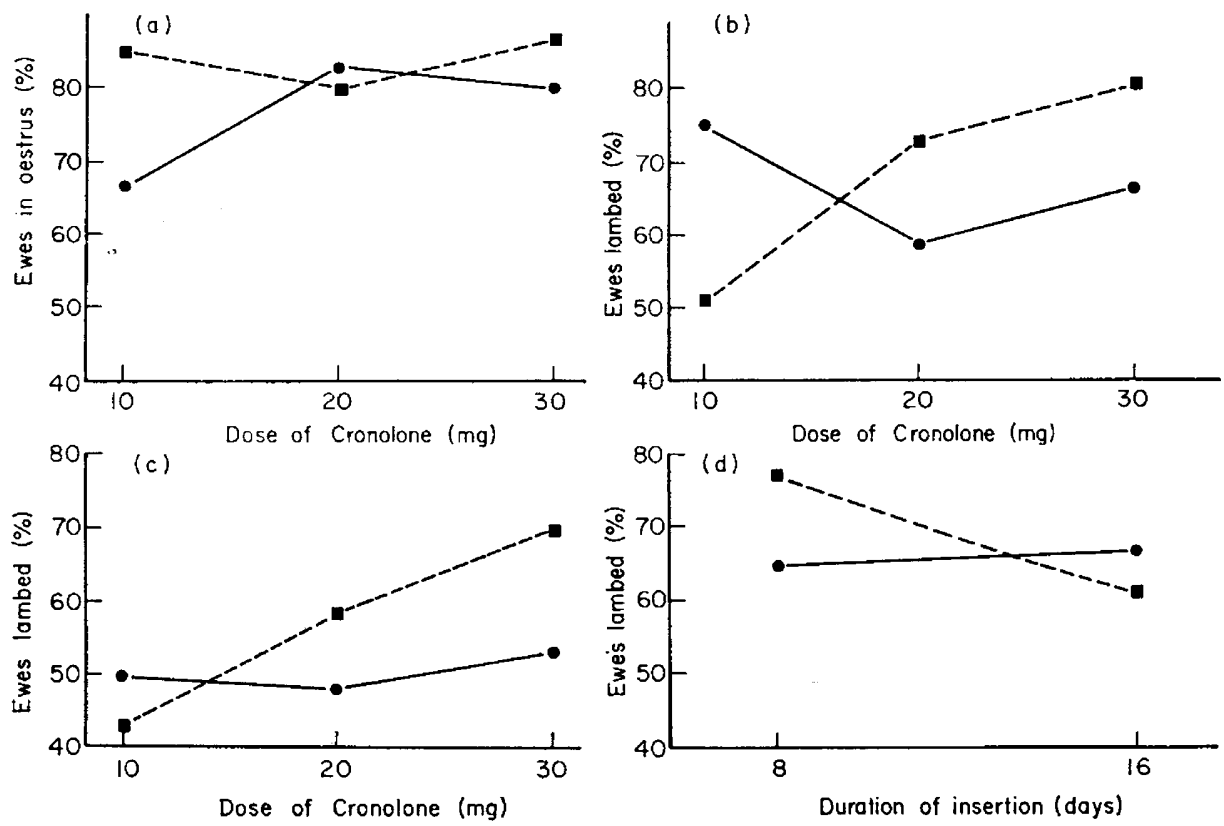

TEXT-FIG. 1. Interactions between method of drying of intravaginal sponges and dose of Cronolone used for impregnation and duration of insertion on ewes in oestrus and ewes which lambed. (a) Ewes in oestrus: method of drying $\times$ dose (quadratic); $P<0.05$. (b) Ewes lambed of ewes in oestrus: method of drying $\times$ dose (linear); $P<0.01$. (c) Ewes lambed of total treated: method of drying $\times$ dose (linear); $0.05<P<0 \cdot 10$. (d) Ewes lambed of ewes in oestrus: method of drying $\times$ duration of insertion; $P \fallingdotseq 0.01$.

Oven-dried; O, air-dried.

\section{Lambing data}

Table 1 presents the data for ewes which lambed as a result of service immediately after treatment, classed for main treatment effects. Overall, 194 lambed $(67.1 \%$ of ewes in oestrus or $53.9 \%$ of all ewes treated).

There were no significant average effects of duration of insertion or of method of preparation of sponges. However, there were several interactions involving the latter which showed method of drying to have had some important effects. There was a significant overall effect of dose of Cronolone on the percentage of ewes which lambed of ewes treated $(10 \mathrm{mg}, 46.7 ; 20 \mathrm{mg}$, $53.3 ; 30 \mathrm{mg}, 61.7 \% ; P<0.05)$, but the apparent linear effect based on ewes in oestrus was not significant $(F=2.52$; d.f. $=1: \infty ; 0 \cdot 10<P<0.20)$. There 
was a highly significant decline in fertility with successive days of withdrawal of sponges, based either on total ewes or ewes in oestrus $(P<0.01)$.

Text-fig. 1(b), (c) and (d) illustrate interactions which either are significant or closely approach significance. The latter are presented because they, probably, are meaningful in the light of the assays on residual Cronolone. Text-fig. 1(b) and (c) show that the effectiveness of the oven-dried sponge increased with increasing dose, whereas that of the air-dried sponge did not, based on ewes lambed of ewes in oestrus $(P<0.01)$ or on ewes lambed of total treated $(0 \cdot 05<P<0 \cdot 10)$. Text-fig. 1 (d) shows that the effectiveness of the ovendried sponge appeared to fall with increasing duration of insertion while that of the air-dried remained constant $(P \fallingdotseq 0 \cdot 10)$. This is consistent with the more rapid rate of absorption from the oven-dried sponges and the failure of the 16-day, 10-mg, oven-dried sponge. By contrast, the overall performance following treatment for 16 days with $30-\mathrm{mg}$ oven-dried sponges was highly satisfactory. Of thirty ewes treated, all came into oestrus and twenty-two lambed $(73.3 \%$ of ewes treated; Table 2$)$.

There appeared to be a relationship between day of oestrus after sponge withdrawal and fertility (Table 3 ) but this was not significant.

TABLE 4

MEAN RESIDUAL GRONOLONE IN INTRAVAGINAL SPONGES

\begin{tabular}{c|l|rrr}
\hline \multirow{2}{*}{$\begin{array}{c}\text { Duration of } \\
\text { insertion } \\
\text { (days) }\end{array}$} & $\begin{array}{c}\text { Method of } \\
\text { preparation }\end{array}$ & \multicolumn{3}{|c}{$\begin{array}{c}\text { Reputed initial dose } \\
\text { of Cronolone (mg) }\end{array}$} \\
\cline { 3 - 5 } & & \multicolumn{1}{|c}{10} & 20 & 30 \\
\hline \multirow{2}{*}{0} & Air-dried & $9 \cdot 4$ & $19 \cdot 2$ & $32 \cdot 1$ \\
& Oven-dried & $10 \cdot 2$ & $19 \cdot 6$ & $28 \cdot 2$ \\
& Air-dried & $7 \cdot 3$ & $12 \cdot 5$ & $24 \cdot 4$ \\
& Oven-dried & $4 \cdot 4$ & $13 \cdot 1$ & $17 \cdot 7$ \\
& Air-dried & $4 \cdot 8$ & $10 \cdot 5$ & $20 \cdot 6$ \\
& Oven-dried & $3 \cdot 3$ & $7 \cdot 7$ & $14 \cdot 8$ \\
& & & & \\
\hline
\end{tabular}

Each estimate is a mean of five analyses.

\section{Absorption of Cronolone}

Table 4 presents the estimates of the mean residual Cronolone in sponges, and Table 5 is an analysis of variance after log transformation. Apart from the effect of initial dose of Cronolone, there were highly significant effects of duration of insertion $(P \ll 0.001)$ and of method of preparation $(P<0.001)$. The quantity recovered from oven-dried sponges after insertion was less than that from air-dried.

There were two important interactions, namely between duration of insertion (linear) and method of preparation $(P<0.002)$ and initial dose of Cronolone $(P<0.002)$. The rate of absorption from oven-dried sponges was greater than that from air-dried and there was a linear increase in the rate with increasing initial dose.

The absence of any significant quadratic component involving duration of 
TABLE 5

ANALYSIS OF VARIANGE OF DATA FOR RESIDUAL GRONOLONE IN INTRAVAGINAL SPONGES AFTER 0-, 8- OR 16-DAY INSERTION: LOG $_{10}$ TRANSFORMATION

\begin{tabular}{|c|c|c|c|c|}
\hline Source of variation & $\begin{array}{l}\text { Degrees } \\
\text { of } \\
\text { freedom }\end{array}$ & Mean square & $F$ & $\boldsymbol{P}$ \\
\hline $\begin{array}{l}\text { Main effects } \\
\text { Duration of insertion } \\
\text { Linear } \\
\text { Quadratic }\end{array}$ & $\begin{array}{l}(2) \\
1 \\
1\end{array}$ & $\begin{array}{l}1 \cdot 66935 \\
0 \cdot 01510\end{array}$ & $202 \cdot 84$ & $\ll 0.001$ \\
\hline $\begin{array}{l}\text { Method of preparation } \\
\text { Dose of Cronolone }\end{array}$ & $\begin{array}{c}1 \\
(2)\end{array}$ & & 22.75 & $<0.001$ \\
\hline $\begin{array}{l}\text { Linear } \\
\text { Quadratic }\end{array}$ & $\begin{array}{l}1 \\
1\end{array}$ & $\begin{array}{l}4.94250 \\
0.05917\end{array}$ & $\begin{array}{r}600 \cdot 55 \\
7 \cdot 19\end{array}$ & $\begin{array}{l}\ll 0.001 \\
<0.01\end{array}$ \\
\hline $\begin{array}{cl}\text { Interactions } & \\
\text { Method } \times \text { duration } & (\text { (1) } \\
\times \text { dose } & (\mathbf{q}) \\
& (1) \\
& (\mathbf{q})\end{array}$ & $\begin{array}{l}1 \\
1 \\
1 \\
1\end{array}$ & $\begin{array}{l}0.08854 \\
0 \cdot 00791 \\
0 \cdot 00010 \\
0 \cdot 02389\end{array}$ & $10 \cdot 76$ & $<0.002$ \\
\hline $\begin{aligned} & \text { Duration (l) } \times \text { dose }(\text { l) } \\
&(\mathrm{q}) \times \text { dose }(\mathrm{q}) \\
&(\mathrm{l}) \\
& \text { Method } \times \text { duration } \times \text { dose } \\
& \text { Remainder (error) }\end{aligned}$ & $\begin{array}{r}1 \\
1 \\
1 \\
1 \\
4 \\
72\end{array}$ & $\begin{array}{l}0 \cdot 09103 \\
0 \cdot 00154 \\
0 \cdot 00073 \\
0 \cdot 00266 \\
0 \cdot 01592 \\
0 \cdot 00823\end{array}$ & $11 \cdot 06$ & $<0.002$ \\
\hline Total & 89 & & & \\
\hline
\end{tabular}

TABLE 6

RATE OF ABSORPTION OF GRONOLONE FROM INTRAVAGINAL SPONGES INSERTED FOR 16 DAYS

\begin{tabular}{|c|c|c|c|c|c|}
\hline \multicolumn{2}{|c|}{ Initial dose } & \multirow{2}{*}{$\begin{array}{c}\text { Residual } \\
\text { Cronolone } \\
\text { after } 16 \text { days } \\
(\mathrm{mg})\end{array}$} & \multicolumn{2}{|c|}{$\begin{array}{l}\text { Absorbed } \\
\text { Cronolone }\end{array}$} & \multirow{2}{*}{$\begin{array}{l}\text { Mean daily } \\
\text { rate of } \\
\text { absorption } \\
(\%)\end{array}$} \\
\hline $\begin{array}{c}\text { Reputed } \\
(\mathrm{mg})\end{array}$ & $\begin{array}{c}\text { Estimated } \\
(\mathrm{mg})\end{array}$ & & $(m g)$ & $(\%)$ & \\
\hline $\begin{array}{c}\text { Oven-dried } \\
10 \\
20 \\
30\end{array}$ & $\begin{array}{l}10 \cdot 2 \\
19 \cdot 6 \\
28 \cdot 2\end{array}$ & $\begin{array}{r}3.3 \\
7.7 \\
14.8\end{array}$ & $\begin{array}{r}6.9 \\
11.9 \\
13.4\end{array}$ & $\begin{array}{l}67.6 \\
60 \cdot 7 \\
47.5\end{array}$ & $\begin{array}{l}8.0 \\
5.5 \\
4.9\end{array}$ \\
\hline $\begin{array}{c}\text { Air-dried } \\
10 \\
20 \\
30\end{array}$ & $\begin{array}{r}9 \cdot 4 \\
19 \cdot 2 \\
32 \cdot 1\end{array}$ & $\begin{array}{r}4.8 \\
10.5 \\
20.6\end{array}$ & $\begin{array}{r}4 \cdot 6 \\
8 \cdot 7 \\
11.5\end{array}$ & $\begin{array}{l}52 \cdot 0 \\
45 \cdot 3 \\
35 \cdot 8\end{array}$ & $\begin{array}{l}4 \cdot 5 \\
4 \cdot 3 \\
2 \cdot 7\end{array}$ \\
\hline
\end{tabular}

* Calculated as a percentage of the quantity remaining in the sponge each day. 
insertion shows that, generally speaking, the rate of absorption is a constant function of the quantity of steroid present in the sponge at any time. Table 6 shows the estimated percentage of Cronolone absorbed over a 16-day period for air- and oven-dried sponges, together with the estimated mean daily rates of absorption. The mean rate of absorption from oven-dried sponges was almost twice that from air-dried $(6.2 \%$ versus $3.7 \% /$ day, Text-fig. $2 \mathrm{a})$ and from $10-\mathrm{mg}$ sponges almost twice that from $30 \mathrm{mg}$ (oven-dried, 8.0 versus 4.9 ; air-dried, 4.5 versus $2.7 \%$ /day; Text-fig. $2 b$ ).
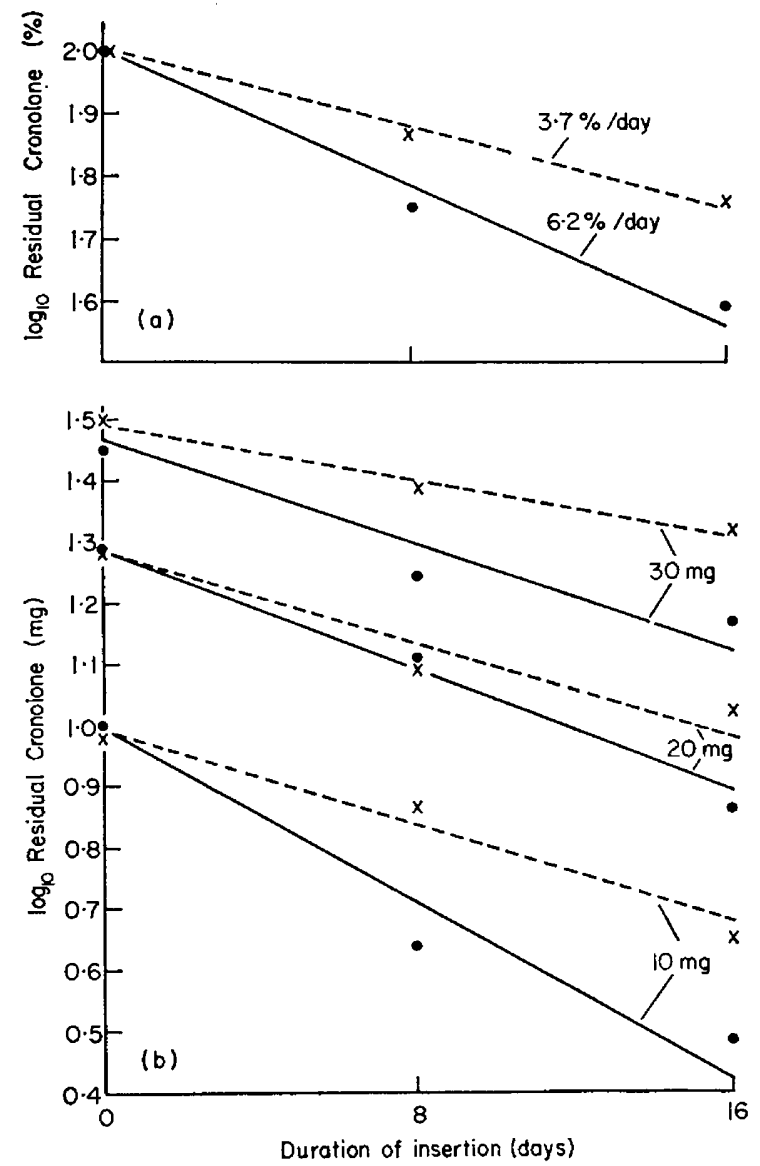

Text-pig. 2. Rate of absorption of Cronolone from air-dried (-- ) and oven-dried (- - ) sponges inserted intravaginally in ewes for 0,8 or 16 days. (a) Mean rate expressed as log percentage of original dose. (b) Individual rates for original doses of 10,20 and $30 \mathrm{mg}$.

\section{DISCUSSION}

The inclusion of the 8-day insertion treatment was intended to provide a midpoint in a three-point assay for rate of absorption. As would be expected, the number of ewes in synchronized oestrus, following cessation of treatment, was less than that following the 16-day insertion. 
The results clearly show the importance of both the initial quantity of progestagen present and its availability. The cumulative improvement in effectiveness of dose of Cronolone from 10 to $30 \mathrm{mg}$ in percentage of ewes in oestrus and percentage of oestrous ewes which conceived is shown by the significant increase from 47 to $62 \%$ of total ewes which lambed. The overall lambing percentage was moderately satisfactory, and in the best treatment combination (30 mg oven-dried sponges) was highly satisfactory in that all of the thirty ewes treated came into oestrus within 5 days after treatment and twenty-two $(73.3 \%)$ lambed.

Relative failures to exhibit oestrus following a full 16-day insertion were associated with low dosage (10 mg) and air-drying. Such sponges, after 16-days' insertion, contained on average about $4.8 \mathrm{mg}$ steroid (actual range of five assays: 1.9 to $6.8 \mathrm{mg}$ ) and, on the basis of a daily rate of absorption of about $4.5 \%$, would be expected to release an average of about $0.21 \mathrm{mg}$ Cronolone over the last day or so, with a proportion releasing considerably less. Such quantities would be somewhat lower than the amount released by the ovendried, $10-\mathrm{mg}$ sponge, namely a mean of $8 \%$ of $3.3 \mathrm{mg}$ or $0.26 \mathrm{mg}$. This assumes, of course, that the rate of absorption is strictly a linear function of the quantity present at any one time, as indicated by the analysis. A slight slowing down of the rate of absorption over the last few days, which might be expected as a result of factors such as a high cholesterol content of the sponges (Morgan et al., 1967) or of differential early absorption of smaller crystals, would reduce these estimates.

It is obvious that the successful use of the progestagen-impregnated intravaginal sponge for the control of the oestrous cycle depends upon the absorption of an effective dose and that this can be affected by a number of factors including method of drying, initial dose of steroid, density of the sponge (Morgan et al., 1967) and volume of ethanol used for impregnation (unpublished data). In the present experiment, high efficiency of synchronization and of subsequent fertility were obtained with a total mean absorption of $13.4 \mathrm{mg}$ Cronolone over 16 days (actual range of five assays: 12.2 to $15.7 \mathrm{mg}$ ), as provided by sponges impregnated with $30 \mathrm{mg}$ Cronolone in $1 \mathrm{ml}$ ethanol and oven-dried. This is not to say that this is the ideal method of preparation, or that this is the optimum dose of Cronolone. A higher rate of release can be obtained using $5 \mathrm{ml}$ of ethanol for impregnation (unpublished data) and more information is required on the relationship between total absorption, rate of absorption and subsequent fertility before the full potential of this technique can be assessed.

Several additional observations are important. Sponges were withdrawn in three batches at intervals of 2 days. This was associated with a significant linear decline in the numbers of ewes mated, the percentage of these which lambed, and the percentage which lambed of all ewes treated. This is a measure of the efficiency of the rams $(10 \%$ were joined) to serve oestrous ewes and to impregnate them. This phenomenon has been observed and discussed previously (Robinson \& Moore, 1967; Robinson, Salamon, Moore \& Smith, 1967). Roberts (1966) withdrew sponges impregnated with 60 or $80 \mathrm{mg}$ MAP on successive days after 13,15 or 17 days' insertion and attributed to duration of 
insertion the linear declines in ewes detected in oestrus and in oestrous ewes which conceived. While there exists the possibility of an effect of duration of insertion, and consequent terminal dose of impregnating steroid, this is likely to be small compared with the effects of satiety of the rams on the efficiency of detection of oestrus and day-to-day variations in semen quality on fertility.

The reason for the effect on fertility of dose of Cronolone is not clear. Several thresholds are involved (Robinson, 1967). First, the dose required to inhibit ovulation in the ewe is lower than that required to condition for oestrus. Second, the dose required to condition for oestrus is lower than that required for full fertility. This phenomenon has been observed in a number of studies (e.g. Robinson \& Smith, 1967; Robinson, Salamon, Moore \& Smith, 1967) although often, as in this study, it has been marginally significant. In the present study the percentage of oestrous ewes which lambed increased from 61.5 to 65.3 to $74.0 \%$ with increasing dose of Cronolone from 10 to 20 to $30 \mathrm{mg}$. This, added to the non-significant increase in oestrous response from 75.8 to 81.7 to $83.3 \%$, resulted in a significant overall increase in fertility from 46.7 to 53.3 to $61.7 \%$, based on all ewes treated $(P<0.05)$. It would be interesting to know whether or not the changed pattern of sperm transport and survival reported by Quinlivan \& Robinson (1967) in progestagen-treated ewes can be modified by altering the dose of progestagen or the method of impregnation of the sponge.

Finally, the relationship between time of onset of oestrus and of fertility must be mentioned. This experiment was characterized by a curious shift in the pattern of time of onset of oestrus with successive days of sponge withdrawal. The earlier time of onset in the ewes treated later cannot be explained. Early onset is associated with reduced fertility. This, of course, is confounded with the amount of Cronolone absorbed and has been a consistent feature of previous studies (Robinson \& Moore, 1967). A high proportion of ewes coming into oestrus on the day following withdrawal of sponges is indicative of inadequate dosage of progestagen and consequent low fertility.

\section{ACKNOWLEDGMENTS}

Grateful acknowledgment is made to the Trustees and the Manager of the McGaughey Memorial Institute, Jerilderie, N.S.W., for the provision of sheep and facilities.

Materials and financial support were supplied by G. D. Searle and Co., High Wycombe, England, and Chicago, U.S.A.

Mr T. D. Quinlivan was holder of a Sir Walter Mulholland Fellowship from New Zealand.

Field assistance was rendered by Messrs I. D. Killeen, D. Maddy and A. Barnes.

\section{REFERENCES}

Clark, J. N., Roberts, E. M., Carter, A. H. \& Kirton, A. H. (1966) Hormonal synchronization of oestrus in Romney ewes during the breeding season. Proc. N.Z. Soc. Anim. Prod. 26, 107.

Morgan, J., LACK, R. E. \& Robinson, T. J. (1967) The rate of absorption of SC-9880 from impregnated sponges inserted intravaginally in cyclic crossbred ewes. In: The Control of the Ovarian Cycle in the Sheep, p. 195. Ed. T. J. Robinson. Sydney University Press. 
Quinlivan, T. D. (1967) Studies in ovine reproduction. Ph.D. thesis, University of Sydney.

Quinlivan, T. D. \& Robinson, T. J. (1967) The number of spermatozoa in the fallopian tubes of ewes at intervals after artificial insemination following withdrawal of SC-9880-impregnated intravaginal sponges. In: The Control of the Ovarian Cycle in the Sheep, p. 177. Sydney University Press.

RoBerts, E. M. (1966) The use of intravaginal sponges impregnated with 6-methyl-17-acetoxyprogesterone (MAP) to synchronize ovarian activity in cyclic Merino ewes. Proc. Aust. Soc. Anim. Prod. 6, 32.

Robinson, T. J. (1964) Synchronization of oestrus in sheep by intravaginal and subcutaneous application of progestin impregnated sponges. Proc. Aust. Soc. Anim. Prod. 5, 47.

RoBinson, T. J. (1965) Use of progestagen-impregnated sponges inserted intravaginally or subcutaneously for the control of the oestrous cycle in the sheep. Nature, Lond. 206, 39.

Robinson, T. J. (1967) Conclusions. In: The Control of the Ovarian Cycle in the Sheep, pp. 227, 240. Sydney University Press.

RoBrnson, T. J. \& MoORE, N. W. (1967) The evaluation of progesterone and SC-9880-impregnated intravaginal sponges for the synchronization of oestrus for large scale artificial insemination of Merino ewes in spring. In: The Control of the Ovarian Cycle in the Sheep, p. 116. Sydney University Press.

Robinson, T. J., Moore, N. W., Holst, P. J. \& Smith, J. F. (1967) The evaluation of several progestagens administered in intravaginal sponges for the synchronization of oestrus in the entire cyclic Merino ewe. In: The Control of the Ovarian Cycle in the Sheep, p. 76. Sydney University Press.

Robinson, T. J., Salamon, S., Moore, N. W. \& Smith, J. F. (1967) The evaluation of SC-9880-impregnated intravaginal sponges for the synchronization of oestrus for large scale artificial insemination of Merino ewes in summer and autumn. In: The Control of the Ovarian Cycle in the Sheep, p. 208. Sydney University Press.

Robinson, T. J. \& Sмiтh, J. F. (1967) The time of ovulation after withdrawal of SC-9880-impregnated intravaginal sponges from cyclic Merino ewes. In: The Control of the Ovarian Cycle in the Sheep, p. 158. Sydney University Press. 